\title{
Competitiveness as a factor of the company's investment attractiveness
}

\author{
Galina Khokhlova ${ }^{1}$, Natalya Kretova $^{1, *}$, and Vadim Sergeev ${ }^{2}$ \\ ${ }^{1}$ Irkutsk National Research Technical Universit, 664074, Lermontova str., 83, Irkutsk, Russia \\ ${ }^{2}$ Angarsk State Technical University, 665835, Chaikovsky str., 60, Angarsk, Russia
}

\begin{abstract}
The purpose of this paper is to substantiate the methodological aspects of assessing the competitiveness of an enterprise and develop proposals based on the practical testing of the assessment model application using an integral indicator. In this article, the object of the research is competitiveness as a factor of investment attractiveness of the enterprise. The subject of the study is the methodological aspects of assessing competitiveness of an enterprise. To achieve this goal, the following research tasks are set: 1) identification of the main problems and reserves of increasing the investment attractiveness of economic entities in Russia; 2) determination of the specifics of analysis of the economic entities competitiveness depending on the assessment criteria; and 3) development of recommendations for improving the quality of the enterprise competitiveness analysis.
\end{abstract}

\section{Introduction}

Today, many advanced entrepreneurs have already appeared in Russia, but at the same time the level of economic performance of the totality of firms, corporations, and other business structures is much lower than that achieved in the entrepreneurial practice of the developed countries $[14,16]$. On average, labor productivity and overall efficiency in the best Russian corporations are 5-6 times or more lower than in similar western ones [10].

A significant increase in the investment attractiveness for many regions of Russia requires significant investments and a long time for the implementation of investment projects. Reserves for improving the investment climate in Russia are connected with the need to develop scientifically sound investment policies at various levels of management, which will allow:

- $\quad$ improving the quality of goods and the competitiveness of domestic enterprises;

- $\quad$ ensuring the growth of productivity and production efficiency;

- $\quad$ achieving national security of the state.

The factors enumerated above acquire particular relevance in the current conditions of political and economic instability in the world $[12,15]$.

\footnotetext{
*Corresponding author: vip.kretova@ inbox.ru
} 
The issue of the competitiveness of industries and national economies was developed in the works of the American scientist M. Porter who, on the basis of the category "competitiveness", studied the problems of competition and competitive advantages in the global economy, researched new trends in international economic relations, and analyzed interbranch economic relations.

In his research, M. Porter used the data of specific sectors of the economies of various countries of the world [6], [7]. Herewith, the theoretical postulates of his research were supported by empirical material of many real examples of the global practice [8].

The study of competitiveness in the framework of innovation and investment development has received significant attention in the works of such authors as Yu.V. Yakovets [17], A.N. Folomiev, E.A. Geiger [3], A.I. Prigogine [9], B.A. Lundval [5], P.F. Drucker [1], B. Santo [11], W. Sharpe, G. Alexander, J. Bailey, [13], R.A. Fathuttinov [2].

The analysis of research in this field showed that the competitiveness of an economic entity is characterized by the stability of its position on the market and is defined by the indicators that specify the determinants of competitive advantages [4].

In turn, the main indicators of competitiveness of economic entities are determined depending on the level of management and the objects of research. In particular, the competitiveness of an enterprise is an integral numerical characteristic, by the means of which the final results of the enterprise activities are achieved and the quality of its products, etc. is assessed.

\section{Materials and Methods}

In order to analyze the competitiveness of economic entities, models based on different criteria and indicators are used, as shown in the Table 1.

Table 1. Models of the competitiveness assessment of an enterprise.

\begin{tabular}{|c|c|c|}
\hline No & Assessment criteria & Contents \\
\hline 1 & Cost price of the products & $\begin{array}{l}\text { The analysis of competitiveness of an economic entity } \\
\text { is conducted from the perspective of advantages based } \\
\text { on the criterion of the cost price of the products. }\end{array}$ \\
\hline 2. & $\begin{array}{l}\text { The volume of output and } \\
\text { sales of the products }\end{array}$ & $\begin{array}{l}\text { The analysis of competitiveness from the position of } \\
\text { the theory of equilibrium is based on the assertion that } \\
\text { if the producer has reached the maximum volume of } \\
\text { output and sales with a constant level of demand, then } \\
\text { he receives the maximum amount of profit, and } \\
\text { accordingly, has a competitive advantage. }\end{array}$ \\
\hline 3. & $\begin{array}{l}\text { Monopolization of the } \\
\text { industry }\end{array}$ & $\begin{array}{l}\text { The analysis of the level of monopolization of the } \\
\text { industry (the difficulty of overcoming barriers to the } \\
\text { development of production in this industry). The } \\
\text { higher is the degree of concentration of capital and } \\
\text { production in the industry, the higher is the level of } \\
\text { competitiveness of economic entities in the industry. } \\
\text { Accordingly, the competitiveness of enterprises in this } \\
\text { industry has a level far higher than the degree of } \\
\text { competitiveness of new enterprises (structural } \\
\text { approach). }\end{array}$ \\
\hline 4. & $\begin{array}{l}\text { Cost/price ratio } \\
\text { (profitability of } \\
\text { production) }\end{array}$ & $\begin{array}{l}\text { The higher is the profitability of the industry, the } \\
\text { higher is the degree of competition and the lower is the } \\
\text { level of competitiveness of enterprises with low } \\
\text { profitability (functional approach). }\end{array}$ \\
\hline
\end{tabular}




\begin{tabular}{|l|l|l|}
\hline 5. & $\begin{array}{l}\text { Customer satisfaction } \\
\text { with a specific product }\end{array}$ & $\begin{array}{l}\text { The analysis of the competitiveness of the analyzed } \\
\text { product with similar values of other competing } \\
\text { products is carried out in the following sequence: 1) } \\
\text { markets are established where the product may be } \\
\text { present; 2) the parameters of the product are } \\
\text { determined, which ensure the maximum profitability } \\
\text { of its sales; 3) the sales activities of the customer are } \\
\text { analyzed in comparison with the performance of } \\
\text { competitors. }\end{array}$ \\
\hline 6. & Use of the BCG matrix & $\begin{array}{l}\text { Calculation of a generalizing index of the enterprise's } \\
\text { competitiveness level. }\end{array}$ \\
\hline
\end{tabular}

In our opinion, the use of the matrix model of the competitiveness assessment gives more valid results, as in the analysis of competitiveness, as a rule, different indicators of enterprises - competitors that are present or may be present in the markets are compared.

In this regard, the purpose of this study is to consider the methodological and practical aspects of assessing the competitiveness of an enterprise on the basis of calculating a generalizing index of the level of competitiveness.

\section{Results}

Calculation of the generalizing index $K_{n}$ of the level of competitiveness of an economic entity can be carried out using the following model:

$$
K_{n}=\sum_{i=1}^{n} a_{i} b_{i j} K_{i j}
$$

fraction of units, where $i$ is the product index;

$n$ is the quantity of goods produced by the enterprise for production is determined $K_{n}$; $a_{i}$ is the specific weight of the $\mathrm{i}^{\text {th }}$ product in the total sales volume for the analyzed period of time, the fraction of units (the analyzed period should be the last period of time depending on the sales range):

$$
a_{i}=\frac{V_{i}}{\sum_{i=1}^{n} V_{i}}
$$

where: $V_{i}$ is the sales volume of the $\mathrm{i}^{\text {th }}$ product for the analyzed period of time in the value units of measurement;

$b_{i j}$ is an indicator of the importance of the $\mathrm{i}^{\text {th }}$ market, where $\mathrm{i}^{\text {th }}$ goods are presented;

$K_{i j}$ is an indicator of competitiveness for single-parameter objects

The value $b_{i j}$ is determined depending on the market in which the goods are sold (Table 2). 
Table 2. Values $b_{i j}$ of the indicator of the importance of the $\mathrm{i}^{\text {th }}$ market, depending on its type.

\begin{tabular}{|l|c|}
\hline \multicolumn{1}{|c|}{ Type of the market } & Value $b_{i j}$ \\
\hline $\begin{array}{l}\text { Industrially developed countries (USA, Western Europe, } \\
\text { Japan, and Canada) }\end{array}$ & 1 \\
\hline Other countries & 0.7 \\
\hline Internal market & 0.5 \\
\hline Various markets & $a_{i .}$ \\
\hline
\end{tabular}

To assess competitiveness, the values $K_{n}$ of the analyzed enterprise are compared with those of other enterprises present on the market or with an indicator ${ }^{`} K_{n}$ corresponding to the priority competitor. Greater competitiveness will have an enterprise, whose value $K_{n}$ is higher. Ideally, the value $K_{n}$ should be 1 .

\section{Results}

Using the above method and the initial data presented in the Table 3, let us calculate and analyze the competitiveness of an enterprise.

Table 3. Initial data for calculating the competitiveness of an enterprise.

\begin{tabular}{|l|c|c|c|c|}
\hline \multirow{2}{*}{ Indicators } & \multicolumn{4}{|c|}{ Goods of the organization } \\
\cline { 2 - 5 } & $\mathrm{A}$ & $\mathrm{B}$ & $\mathrm{C}$ & $\mathrm{D}$ \\
\hline $\begin{array}{l}\text { market on which the } \\
\text { product is present }\end{array}$ & $\begin{array}{c}\text { Of the } \\
\text { developed } \\
\text { countries }\end{array}$ & $\begin{array}{c}\text { Of other } \\
\text { countries }\end{array}$ & \multicolumn{2}{|c|}{ Internal market } \\
\hline $\begin{array}{l}\text { market importance } \\
\text { indicator }\end{array}$ & 1 & 0.7 & 0.5 & 0.5 \\
\hline $\begin{array}{l}\text { level of competitiveness } \\
\text { of goods on a particular } \\
\text { market, }\left(K_{i j}, \text { ) }\right.\end{array}$ & 0.95 & 1.05 & 1.1 & 0.97 \\
\hline $\begin{array}{l}\text { sales of goods on this } \\
\text { market, million dollars }\end{array}$ & 60 & 210 & 730 & 80 \\
\hline $\begin{array}{l}\text { specific weight of goods } \\
\text { in total sales }\end{array}$ & 0.056 & 0.194 & 0.676 & 0.074 \\
\hline
\end{tabular}

Note: each of the products is presented only on one market.

$$
K_{n}=0.056 \cdot 1 \cdot 0.95+0.194 \cdot 0.7 \cdot 1.05+0.676 \cdot 0.5 \cdot 1.1+0.074 \cdot 0.5 \cdot 0.97=0.603 \text {. }
$$

Comparing the values $K_{n}$ of the analyzed enterprise with 1 , it can be concluded that its competitiveness index $(1-0.603)$ is less than the highest value of the world-class enterprise indicator by 0.397 , and that is, it is quite difficult to achieve a competitive advantage on the developed countries market.

\section{Discussion}

Thus, based on the calculations performed, it can be concluded that to increase the competitiveness of an enterprise, it is advisable: 
1) to increase the volumes of production of goods B and C on the external and internal markets;

2) to increase the competitiveness of goods A in order to increase the sales of goods A on the market of the industrially developed countries, while increasing the share of this product in the structure of sales of the enterprise;

3 ) to increase the competitiveness of goods D in order to increase sales and gain greater attractiveness among consumers, which will enable them to increase sales;

4) to remove from production unprofitable goods that will improve the quality and other indicators of the rest of goods.

\section{Conclusion}

To improve the quality of the enterprise competitiveness analysis, certain information on the competitor indices is required, which we propose to classify into particular groups as presented in the Table 4.

Table 4. Initial information for assessing the competitiveness of an enterprise.

\begin{tabular}{|c|c|c|c|c|c|}
\hline \multirow{3}{*}{ Indicators } & \multicolumn{3}{|c|}{$\begin{array}{c}\text { The values of the indicators for the } \\
\text { enterprises of competitors }\end{array}$} & \multicolumn{2}{|c|}{$\begin{array}{c}\text { Indicators of the } \\
\text { organization being } \\
\text { analyzed }\end{array}$} \\
\cline { 2 - 5 } & $\mathrm{K} 1$ & $\mathrm{~K} 2$ & $\mathrm{~K} 3$ & real & predicted \\
\hline
\end{tabular}

1. Useful effect of the goods (integral quality indicator), in units of the useful effect

2. Total costs for the life cycle of a unit of goods

3. The quality of information support and communications

4. The specific weight of this product in the sales of the organization

5. Indicators of the importance of the market on which the product is presented

6. Parameters of the commodity markets

7. The price of the goods, and costs of the goods

Thus, the analysis of the competitiveness of an enterprise using the proposed groups of indicators will allow managing the quantitatively evaluated factors of competitive advantages (indicators) used in calculating the generalized index of the competitiveness of the facility, which may be influenced by factors of the internal environment of the manufacturing enterprise, in the most effective way.

In turn, the results of the analysis of the competitiveness of enterprises are not only an urgent task for a particular business entity, investors and creditors, but are also used to formulate economic policies at the level of regions and the state as a whole.

\section{References}

1. P. Drucker, Management challenges for the 21st century (William, Moscow, 2002)

2. R. A. Fatkhutdinov, The Competitiveness of the organization in a crisis: Economics, marketing, management (Marketing, M.oscow, 2002)

3. A. N. Folomiev, E. A. Geiger, Management of Innovation: Theory and Practice (RAGS Publishing House, Moscow, 1997)

4. C. Freeman, Technology Policy and Economic Performance (London, 1987)

5. B. A. Lundval, National innovation system: towards a theory of innovation and interactive learning (Pinter, London, 1992) 
6. M. E. Porter, Competitive strategy: techniques for analyzing industries and competitors: with a new introduction (Free Press, 1980)

7. Michael E. Porter, Information for competitive advantage, division of research, graduate school of business administration (Harvard University, 1985)

8. M. E. Porter, (1990) The competitive advantage of nations: with a new introduction (Free Press, New York, 1990)

9. A. I. Prigogine, Innovations: incentives and prospects (Politizdat, M., 1998)

10. A. V. Prokopyeva, A. S. Nechaev, Middle East Journal of Scientific Research, 17, 233236 (2013).

11. B. Santo, Innovation as a tool for economic development. (Progress, M., 1990).

12. J. A. Schumpeter, Busness cycle: a theoretical, historical and statistical analysis of the capitalist process (McGraw-Hill Book Company, New York, Toronto, London, 1939)

13. W. Sharpe, G. Alexander, J. Bailey, Investments (Prentice Hall, 1998)

14. The Global Competitiveness Report 2016-2017, 306-307 (2017)

15. M. Y. Veselovsky, M. A. Izmailova, A. V. Bogoviz, S. V. Lobova, Y. V. Ragulina, Quality - Access to Success, 19(163), 30-36 (2018)

16. M. Y. Veselovsky, M. A. Izmailova, A. V. Bogoviz, S. V. Lobova, A. N. Alekseev, Quality - Access to Success, 19(162), 60-66 (2018)

17. Y. V. Yakovets, The Global Economic Transformation of the 21st Century (LAP Lambert Academic Publishing, 2014) 